\title{
Experimental Data of Meat Raw Parameter Change by Electrophysical Impact
}

\author{
${ }^{1}$ Poruchikov Dmitrii, ${ }^{2}$ Vasilyev Alexey, ${ }^{3}$ Samarin Gennady, ${ }^{4}$ Ershova Irina, ${ }^{5}$ Kovalev Andrey, ${ }^{6}$ Fomchenko \\ Alexander, ${ }^{7}$ Normova Tatiana \\ ${ }^{1-4}$ Federal Scientific Agroengineering Center VIM, Russian Federation, Moscow, 1-y Institutsky proezd, 5 \\ ${ }^{5}$ State Budgetary Vocational Educational Institution "Zapadnodvinsky Technological College named after I.A. \\ Kovalev", Russian Federation, Tver region, Western Dvina, Mira street, 12 \\ ${ }^{6}$ Federal State Budgetary Educational Institution of Higher Education "State Agricultural Academy of Velikie \\ Luki", Russian Federation, Pskov region, Velikie Luki, Lenin Aven., 2 \\ ${ }^{7}$ Federal State Budgetary Educational Institution of Higher Education "Kuban State Agrarian University named \\ after I.T. Trubilin", Russian Federation, Krasnodar, Kalinina street, 13 \\ Email: eig85@yandex.ru
}

Received: $19^{\text {th }}$ July 2019, Accepted: $10^{\text {th }}$ August 2019, Published: $31^{\text {st }}$ August 2019

\begin{abstract}
The article describes the device and its operation principle with high frequency and infrared power supply for raw meat salting and heat treatment. The experimental studies of raw meat parameters (pork; muscular stomach; chicken heart) were carried out in the developed device. They provided the results of raw meat heating dynamics study in a resonator-drum of the designed device with different power: $0.8 \mathrm{~W} / \mathrm{g}, 0.4 \mathrm{~W} / \mathrm{g}, 0.16 \mathrm{~W} / \mathrm{g}$, depending on the dose of ultrahigh frequency electromagnetic field, the dynamics of the bird's heart heating when exposed to an ultra-high frequency (UHF) field $(7 \mathrm{~W} / \mathrm{g})$, with complex exposure to microwave $(7 \mathrm{~W} / \mathrm{g})$ and infrared radiation (grill lamp, 0.4 $\mathrm{kW}$ ), the results of brine salt concentration change study and the change of salt content in raw materials during salting.

They developed the response surfaces and two-dimensional sections in performance model isolines of the developed device, exposure dose, bacterial contamination, energy costs depending on the variable parameters (power density, the duration of EMI-UHF effect and rotation frequency).
\end{abstract}

\section{Keywords}

Heat Treatment Device, Electrophysical Effect, Ultra-High Frequency Electromagnetic Field, Raw Meat, Infrared Radiation, Experimental Studies

\section{Introduction}

Currently, as part of the energy saving program, it is proposed to use non-conventional energy sources [10,11,12], including the energy of electromagnetic ultrahigh-frequency studies $[13,14]$.

In Russia, as well as abroad, the technologies for superhigh-frequency (UHF) electronics development are classified as critical technologies. Therefore, the development and justification of the device parameters using electrophysical effects for heat treatment in the process of massaging small-sized meat raw materials is relevant.

On the basis of the conducted analysis of raw meat salting and heat treatment means and methods [1], the device was developed for the heat treatment of raw meat [2].

The authors carried out experimental studies of raw meat parameter changes in the developed device for the heat treatment of raw meat.

The purpose of the study is to analyze the experimental data of raw meat parameter changes by electrophysical effects - the exposure to an electric field of ultra-high frequency (UHF) and infrared exposure (IR).

Device with Microwave and IR Power Supply [3, 4]

The device with microwave and infrared power supply (hereinafter - microwave device) to the resonator-drum of pipes with coolant, providing electrophysical and thermomechanical effects on raw meat [5].

The developed device (patent No. 2537548) contains the resonator chamber 3 in the cylindrical shielding housing 1 in the form of a squirrel cage assembled from pipes, on the end of which the emitter is directed from the generator unit 5 with the magnetron. The hollow shaft 7 is laid through the central axis of the resonator chamber. The shaft is rigidly connected to the end hollow disk 15 and the annular tube 6 of the resonator chamber. The generator unit and the charging port 12 are located on the side of the resonator open end. The bottom of the body has a drain nipple 14 . The resonator contains blades 4 . The grill-lamp 2 is installed under the body. The curing brine seeps through the slots 13 between the pipes to the bottom of the body and fills a part of raw meat in the chamber. There is the partition 18 in the middle of the hollow shaft 4 (Figure 1) [3]. 

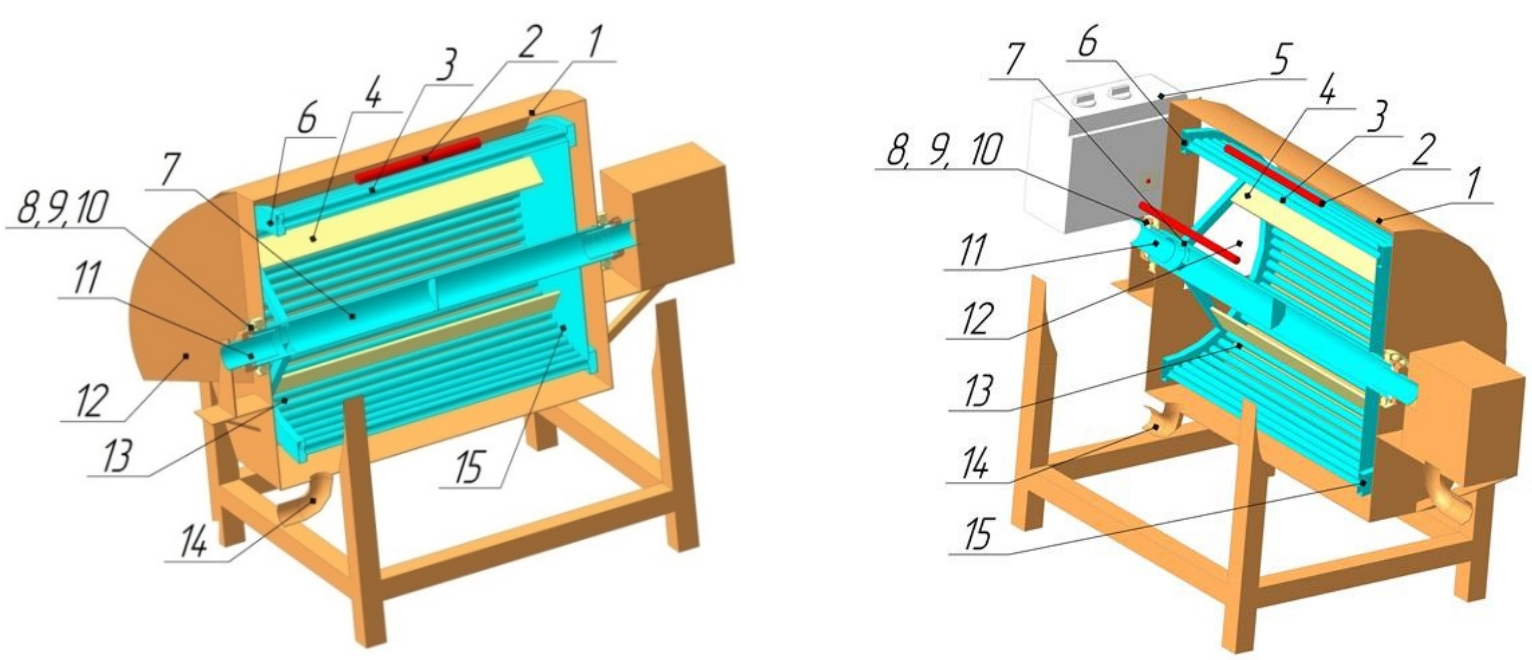

Figure 1: The Device of Microwave and Infrared Power Supply to the Tubular Resonator-Drum with Heat Carrier, Providing Thermomechanical Effect on Raw Meat

1: Shielding Housing; 2: Grill Lamp; 3: Resonator Chamber in the Form of Squirrel Cage; 4: Blades; 5: Generator Unit; 6: Ring Pipe; 7: Hollow Shaft; 8: Bearing Unit; 9: Dielectric Strip; 10: Lock Nut; 11: Clutch; 12: Hatch; 13: The Gap between the Pipes; 14: Drain Pipe, 15: Hollow Disk;

The designed device sample is presented on Figure 2.

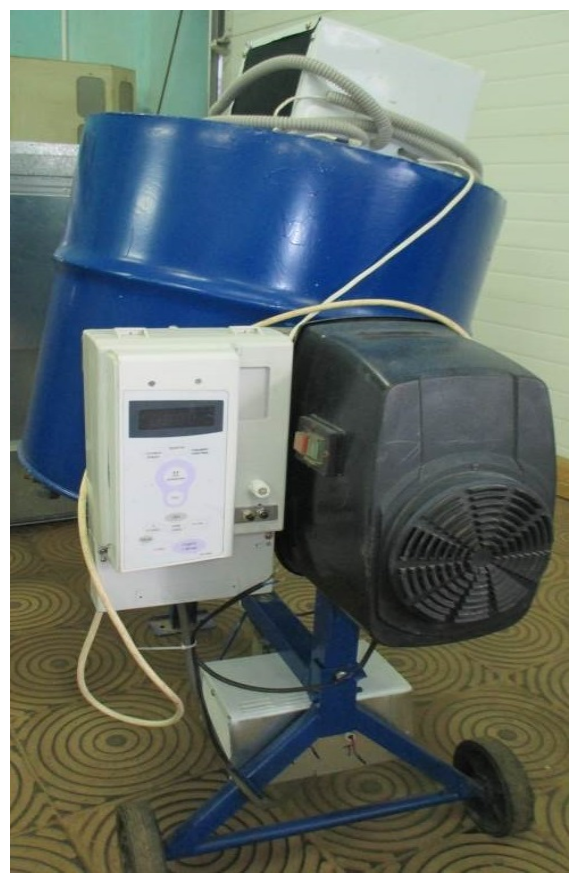

Figure 2: Designed and Manufactured Device Sample with a Resonator-Drum, Made in the Form of a Squirrel Cage for Salting and Heat Treatment of Raw Meat

\section{Experimental Study of Raw Meat Parameters}

The studied raw meat - poultry heart, poultry muscular stomach and pork.

Using the designed and manufactured sample (Figure 2) of the device with a resonator made in the form of a squirrel cage, they studied the temperature variation of raw meat heating temperature by the electrophysical effect of a microwave field of different power $[8,9]$.

The dynamics of raw meat heating in EMI-UHF was studied preliminary in a stationary mode. To do this, they placed a dielectric tray with different raw materials in the resonator chamber without rotation. At the same time, raw meat is heated to $70^{\circ} \mathrm{C}$ in $180 \mathrm{~s}$ at a specific power of $7 \mathrm{~W} / \mathrm{g}$ (Table 1). 


\begin{tabular}{|l|c|c|c|}
\hline $\begin{array}{l}\text { Duration of } \\
\text { exposure, } \mathrm{s}\end{array}$ & $\begin{array}{c}\text { The results of the temperature distribution } \\
\text { study on raw material surface using FLIR } \\
\text { i3 }\end{array}$ & $\begin{array}{c}\text { Duration of } \\
\text { exposure, } \mathrm{s}\end{array}$ & FLIR i3 study results \\
\hline 0 & & & \\
\hline 30 & & & \\
\hline
\end{tabular}

Table 1: The Results of the Temperature Field Distribution Study on Raw Meat Surface 1: Chicken Heart (Left), 2: Chicken Muscle Stomach (Right), 3: Pork Muscle Tissue (Bottom)

The studies of temperature fields, carried out using FLIR i3 thermal imager, show that heat treatment of raw meat in a drum resonator reduces irregularity during the endogenous heating of bird giblets, up to $1-3{ }^{\circ} \mathrm{C}$. With large lumps of raw meat, the temperature deviation by volume reaches $5-10{ }^{\circ} \mathrm{C}[6]$.

The results of small-sized raw meat heating dynamics study in the microwave device prototype with a resonator drum in the form of a squirrel cage (Figure 3). The empirical expressions describing the dynamics of small-sized raw meat heating in the microwave device at different power density: $0.8 \mathrm{~W} / \mathrm{g}, 0.4 \mathrm{~W} / \mathrm{g}, 0.16 \mathrm{~W} / \mathrm{g}$, respectively:

$T=27,836 \cdot \mathrm{e}^{0,1229 \cdot \tau} ; T=24,531 \cdot \mathrm{e}^{0,0958 \cdot \tau} ; T=18,624 \cdot \mathrm{e}^{0,0757 \cdot \tau}$. 


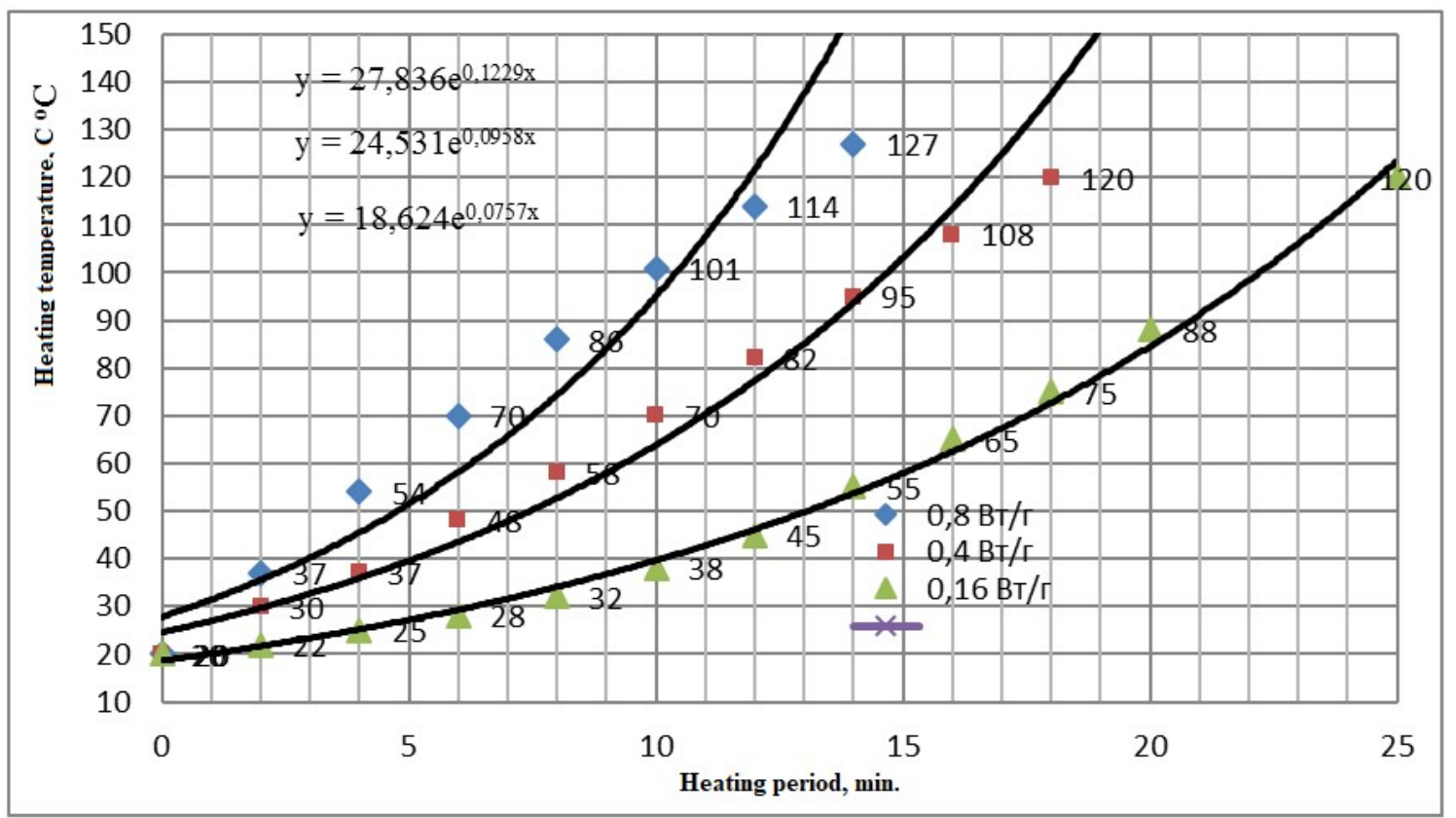

Figure 3: Heating Dynamics of Small-Sized Raw Meat in the Resonator - The Drum of the Microwave Device at Different Power Density: $0.8 \mathrm{~W} / \mathrm{g}, 0.4 \mathrm{~W} / \mathrm{g}, 0.16 \mathrm{~W} / \mathrm{g}$

The experimental studies of raw meat heating dynamics in a microwave device, depending on the specific power and the dose of exposure, were performed using Testo 925 temperature meter (Fig. 4, 5).

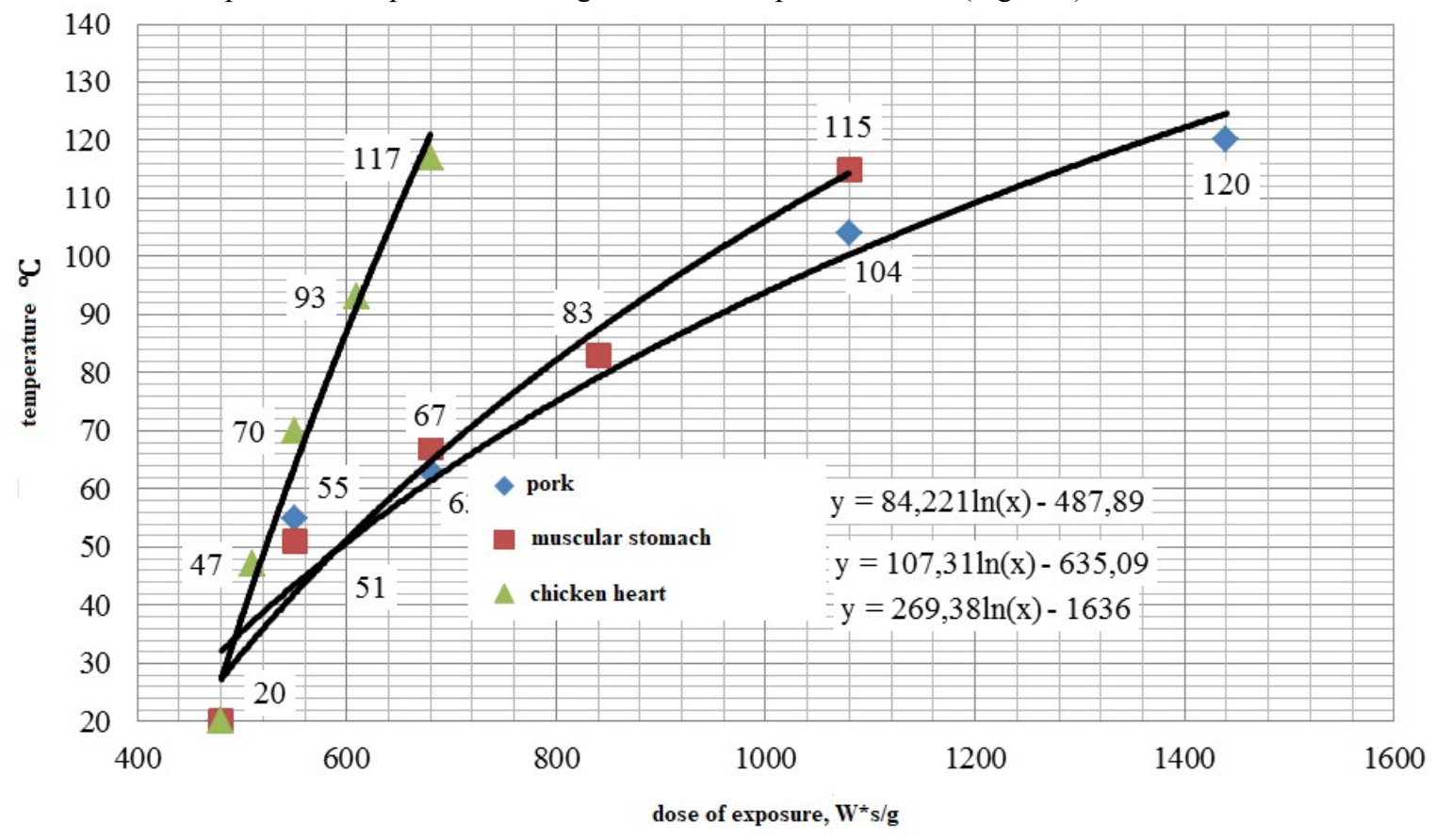

Figure 4: Temperature Variation on the Surface of Raw Meat, Depending on the Dose of Exposure to EMIUHF (1: Pork; 2: Muscular Stomach; 3: Chicken Heart) 


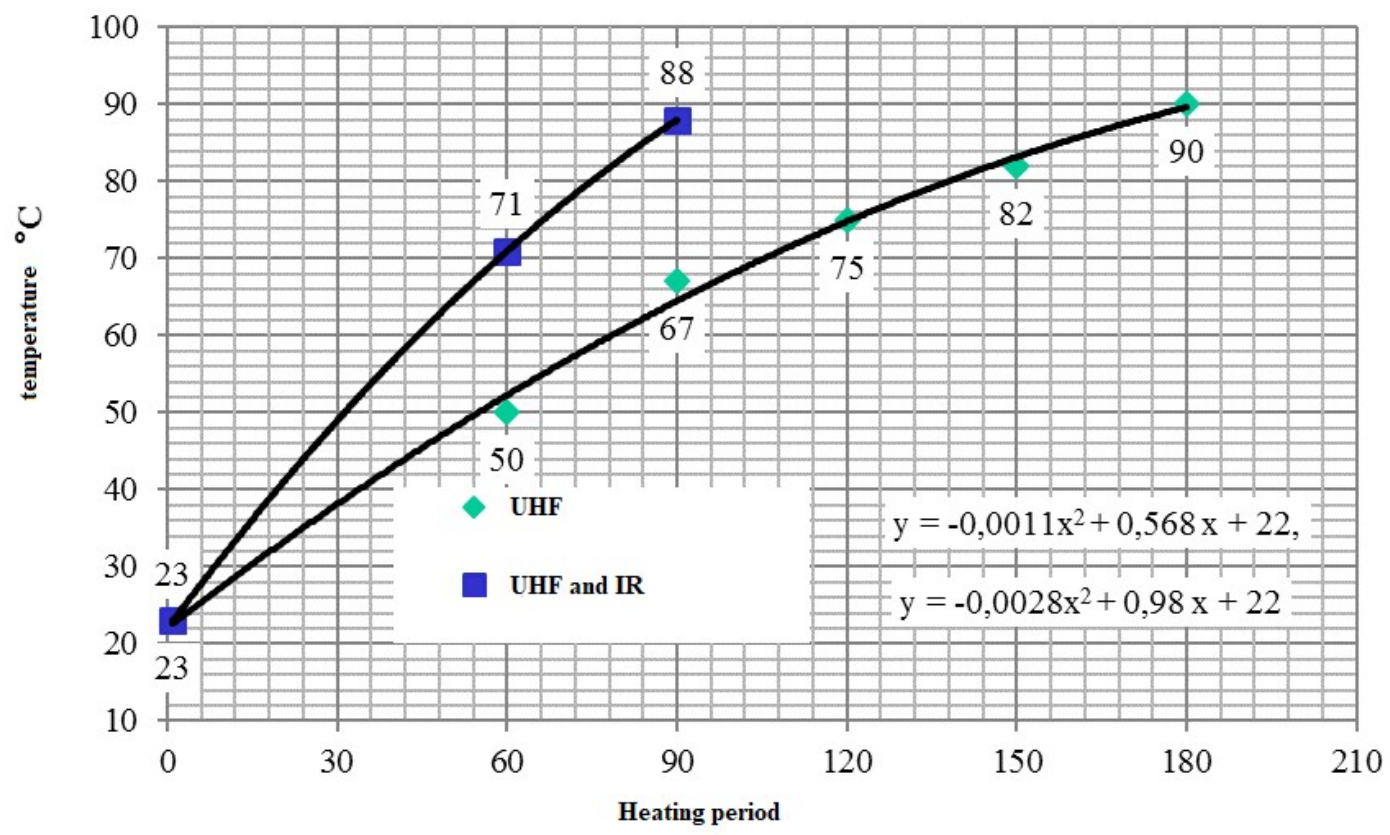

Figure 5: Study Results of the Bird's Heart Heating Dynamics under Different Modes

a) When Exposed to Microwave $(7 \mathrm{~W} / \mathrm{g})$,

b) At Combined Influence with Microwave ( $7 \mathrm{~W} / \mathrm{g})$ and IR (Grill Lamp, $0.4 \mathrm{~kW}$ )

They conducted the study of salt concentration change in brine and salt content change in raw materials at the base and design technology. The studies show that $5.9-6.2 \mathrm{~kg}$ of boiled product can be obtained from $5 \mathrm{~kg}$ of bird's heart in 20-25 minutes, if the generator specific power is $0.16 \mathrm{~W} / \mathrm{g}$, and salt concentration is $12.88 \%$.

The Gambit-120 meat massager was adopted as the base case [7].

The graphs of sodium chloride distribution in brine and raw materials during massaging without exposure and with exposure to EMI-UHF are shown on Fig. 6

An important role in the development of taste and aroma is played by the penetration rate of curing agents into the product. Under the action of EMI-UHF, the meat salting is accelerated. The obtained data allow us to conclude that diffusion-osmotic processes under the influence of microwave waves are intensified to a much greater extent than with conventional mechanical mixing. The main factors that accelerate the penetration of salt into the meat are the processes of cavitation and microwave pressure occurring in the microwave field.

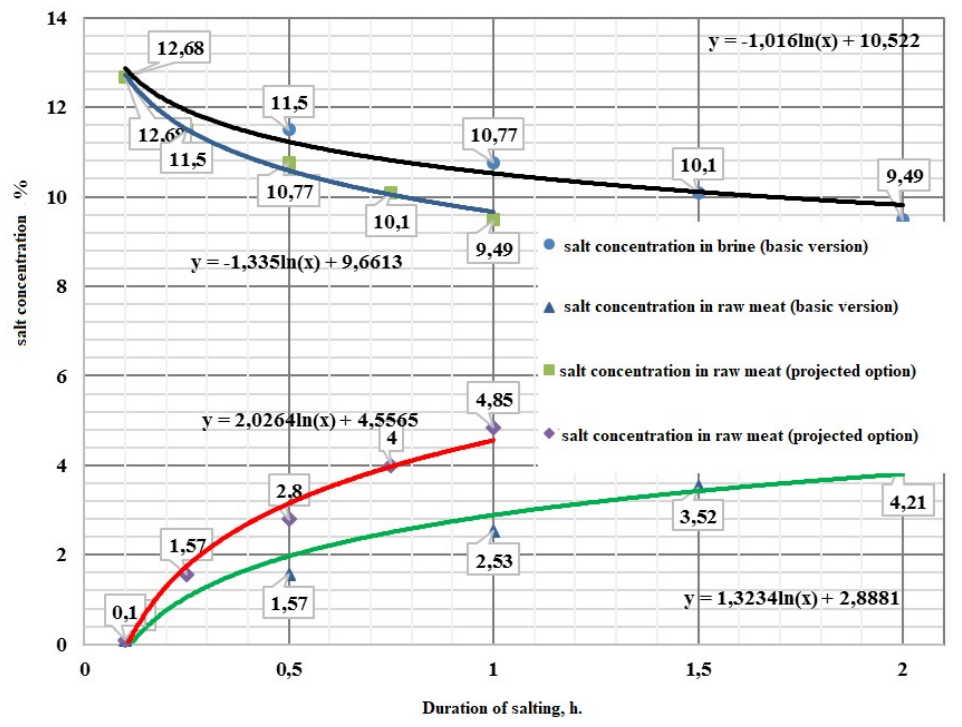

Figure 6: The Change of Brine Concentration and the Change of Salt Content in Raw Materials at the Base (Row 1, 2) and Projected Technology (Row 3, 4) 
Optimization of Heat Treatment and Massing Modes for Raw Meat in the Device Working Chamber Regression dependencies are obtained on the basis of the criterion equations, which make it possible to determine the rational modes of the microwave device [3]. For this, they used the planning matrix of the 3-factor active experiment of the type $2^{3}$. They chose the main factors affecting the process of raw meat salting and heat treatment: the specific power of the microwave generators $\mathrm{R}_{\mathrm{ud}}, \mathrm{W} / \mathrm{g}\left(\mathrm{x}_{1}\right)$; the duration of exposure to EMI-UHF $\tau$, $\mathrm{h}\left(\mathrm{x}_{2}\right)$; the rotational speed of the working chamber $\mathrm{n}, \mathrm{rpm}\left(\mathrm{x}_{3}\right)$. The choice of factor change intervals due to technological conditions and design parameters of the microwave device. The factors were compatible and not correlated with each other, and the limits of their changes were taken as follows:
$\left(x_{1}\right) 0,08 \cdot 10^{-3} \leq P_{y d} \leq 0,4 \cdot 10^{-3} \mathrm{~W} / \mathrm{kg}$;
( $\left.x_{2}\right) 0,5 \leq \tau \leq 1 \mathrm{~h}$;
$\left(x_{3}\right) 13 \leq n \leq 33 \mathrm{rev} / \mathrm{min}$.
Optimization criteria are the following ones:
$Y_{1}$ - the performance of the microwave device $(\mathrm{Q}, \mathrm{kg} / \mathrm{h})$;
$Y_{2}$ - the dose of exposure to EMI-UHF (D, W/h/ kg);
$Y_{3}$ - bacterial contamination $(\mathrm{TMC}, \mathrm{CFU} / \mathrm{g})$;
$Y_{4}$ - energy costs for the process $(W, \mathrm{~kW} \cdot \mathrm{h} / \mathrm{kg})$.

The regression models of raw meat heat treatment in coded units at $\mathrm{x}_{3}=+1(33 \mathrm{rpm})$ and at $\mathrm{x}_{3}=-1(13 \mathrm{rpm})$ are shown below. The regression equations adequately describe the process of raw meat heat treatment under the influence of the studied factors. Using the program "Statistic V12.0", response surfaces and their two-dimensional sections in contour lines (Fig. 9) were developed. From the analysis of the equations, such operating modes of the device were revealed that ensure the minimum of specific energy expenditures for heat treatment and raw meat massaging and maximum reduction of its microbiological seeding. Enter $\mathrm{x}_{1}, \mathrm{x}_{2}, \mathrm{x}_{3}$ factors in named units to the regression equation. The absolute value of the factor at any level is determined by the following formula:

$$
X=\frac{x_{i}-x_{i o}}{\Delta x_{i}} \text {, where } x_{i}-\text { the value of the factor at the main (zero) level; } \Delta \mathrm{xi} \text { - the factor variation interval. }
$$

Using STATISTICA 12.0 program, response surfaces and two-dimensional sections were developed in the isolines of device performance models, exposure dose, bacterial contamination, energy consumption depending on the variable parameters (specific power, the duration of EMI-UHF exposure and rotation frequency) (Fig. 8).

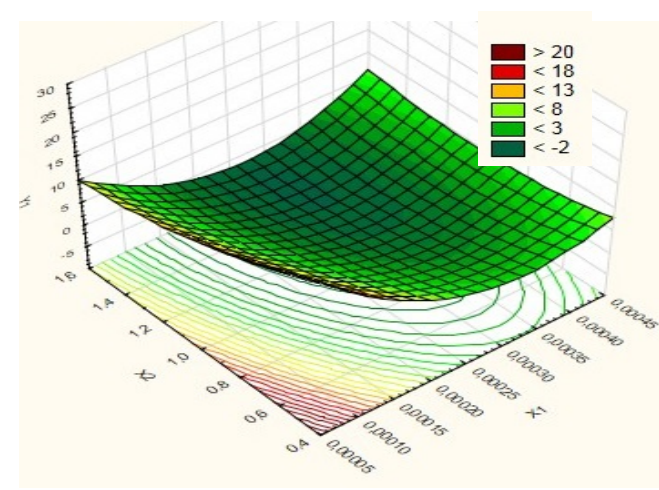

(a)

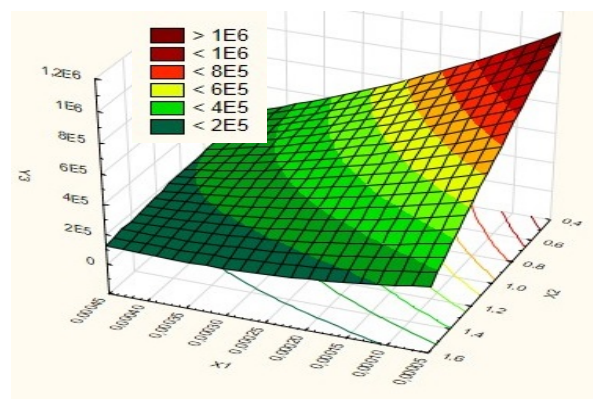

(c)

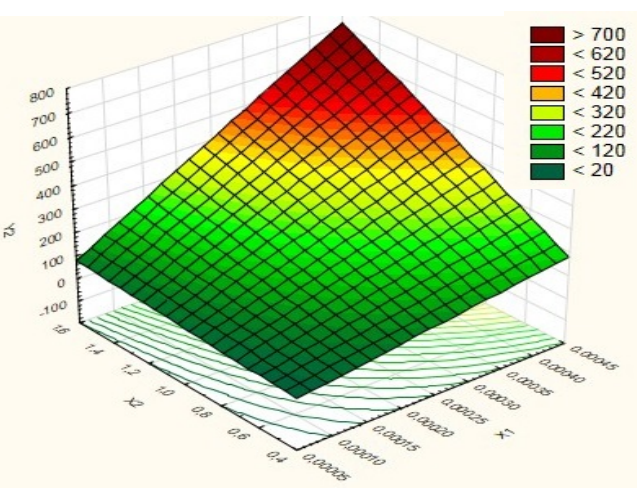

(b)

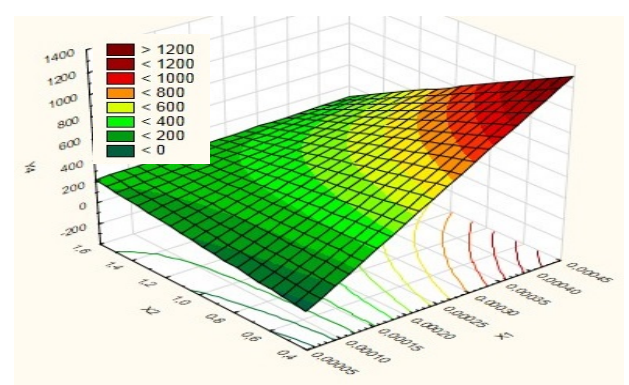

(d)

Figure 8: Response Surface and Two-Dimensional Section in the Isolines of Three-Factor Models, Depending on the Power-Weight Ratio and Processing Time in the Microwave Electromagnetic Field at a Drum Rotation Frequency of 23 rpm: a) Performance; b) Dose of Exposure; c) Total Microbial Number; d) Energy Costs 
The obtained empirical expressions characterize the dependence of optimization criteria on variable parameters.

$$
\begin{aligned}
& Q=42,29-1,79 \cdot 10^{5} \cdot x_{1}-28,12 \cdot x_{2}+2,53 \cdot 10^{8} \cdot x_{1}^{2}+27865,39 \cdot x_{1} \cdot x_{2}+7,37 \cdot x_{2}^{2} . \\
& D=-0,16+1232734 \cdot x_{1}-1,53 \cdot x_{2}+2,59 \cdot 10^{7} \cdot x_{1}^{2}+1 \cdot 10^{6} \cdot x_{1} \cdot x_{2}+0,73 \cdot x_{2}^{2} . \\
& O M Y=1,47 \cdot 10^{6}-3,48 \cdot 10^{9} \cdot x_{1}-6,53 \cdot 10^{5} \cdot x_{2}+1,45 \cdot 10^{12} \cdot x_{1}^{2}+1,53 \cdot 10^{9} \cdot x_{1} \cdot x_{2}-539441 \cdot x_{2}^{2} . \\
& W=-356,66+4,46 \cdot 10^{6} \cdot x_{1}+354,91 \cdot x_{2}-6,02 \cdot 10^{7} \cdot x_{1}^{2}-2,66 \cdot 10^{6} \cdot x_{1} \cdot x_{2}-0,15 \cdot x_{2}^{2} .
\end{aligned}
$$

The regression equations describe adequately the process of raw meat heat treatment under the influence of the studied factors.

\section{Conclusion}

They developed the device and device operation principle with microwave and infrared power supply for the heat treatment of raw meat. The experimental studies of raw meat parameters were carried out in the developed device.

The dynamics of raw meat (pork; muscular stomach; chicken heart) heating in a resonator-drum designed microwave device with different power density: $0.8 \mathrm{~W} / \mathrm{g}, 0.4 \mathrm{~W} / \mathrm{g}, 0.16 \mathrm{~W} / \mathrm{g}$.

They provided the dynamics of raw meat heating at different specific powers of the microwave generator: 0.1-0.9 $\mathrm{W} / \mathrm{g}$ for $600 \mathrm{~s}$.

The temperature change over the surface of raw meat is determined depending on the dose of exposure to EMIUHF.

They provided the results of chicken heart heating dynamics study under different modes: during the exposure to microwave $(7 \mathrm{~W} / \mathrm{g})$, at combined exposure to microwave $(7 \mathrm{~W} / \mathrm{g})$ and IR (grill lamp, $0.4 \mathrm{~kW})$

They provided the results of the study concerning salt concentration change in the brine and the change of salt content in raw materials with basic and design technology.

They developed the response surfaces and two-dimensional sections in the isolines of the device performance models, exposure dose, bacterial contamination and energy costs depending on the variable parameters (power density, duration of exposure to EMI-UHF and rotational speed). The obtained empirical expressions characterize the dependence of optimization criteria on variable parameters.

The regression equations adequately describe the process of raw meat heat treatment under the influence of the studied factors.

The optimal performance of the microwave device for raw meat heat treatment and massaging makes $1.33-20 \mathrm{~kg} / \mathrm{h}$ and is achieved with a specific power of $0.08-0.4 \cdot \mathrm{W} / \mathrm{kg}$ and with the processing time of $0.5-1.0 \mathrm{~h}$.

\section{Conflict of Interest}

The authors confirm that the presented data does not contain a conflict of interest.

\section{References}

[1] Poruchikov D.V., Ershova I.G. Overview of the means and methods of salting and heat treatment of meat raw materials / D.V. Poruchikov, I.G. Ershova // State and prospects for the development of the agro-industrial complex, a collection of scientific papers of the XII International Scientific and Practical Conference in the framework of the XXII Agroindustrial Forum of the South of Russia and the exhibition Interagromash. Don State Technical University, Agrarian Scientific Center "Donskoy". Rostov-on-Don: DGTU-PRINT. - 2019.- pp. 609-613

[2] Samodelkin A.G. Analysis of electrophysical parameters of raw meat / A.G. Samodelkin, I.G. Ershova, D.V. Guarantors, M.V. Belova, A.N. Matveeva // Natural and technical sciences. - 2015. - No 6 (84). - pp. 501-504.

[3] Patent No. 2537548 of the Russian Federation IPC A22C 9/00 (2006/01) A23B 4/01 (2006/01). Installation for salting and heat treatment of meat raw materials / D.V. Lieutenants, N.K. Kirillov, G.V. Novikova, M.V. Belova; applicant and patent holder - ChGAA (RU). - No 2013107408/13; declare 02.19.2013; publ. 01.10.2015. Bul No 1.

[4] Patent No 2650540 of the Russian Federation IPC A22C 17/00 (2006.01). Ultra-high-frequency cyclic action installation for heat treatment of raw meat / G.V.Zhdankin, A.G. Samodelkin, D.V. Guarantors, G.V. Novikova, M.V. Belova; applicant and patent holder - FSBEI HE NGAA. - No 2016150295; declare 12.20.2016; publ. 04/16/2018 Bul No 11.

[5] Belova M. V. Innovations in Technologies of Agricultural Raw Materials Processing/ M. V. Belova, G. V. Novikova, I. G. Ershova, M. A. Ershov, O. V. Mikhailova // ARPN Journal of Engineering and Applied Sciences. 2016. T. 11. No 6. pp. 1269-1277.

[6] Samodelkin A.G. Analysis of electrophysical parameters of raw meat / A.G. Samodelkin, I.G. Ershova, D.V. Guarantors, M.V. Belova, A.N. Matveeva // Natural and technical sciences. - 2015. - No 6 (84). - pp. 501-504.

[7] Ershova I.G. Economic efficiency of microwave installation for heat treatment of by-products / M.V. Belova, I.G. Ershova, N.T. Uezdny // International scientific-theoretical and applied journal "Bulletin of the Chuvash State Pedagogical University named after I. Yakovlev." - Cheboksary: CSPU, 2013. - No 4 (80). - pp. 30-33. 
[8] Rodionova, A., V., Borovkov M., S., Ershov, M., A. (2012). Justification of the selected frequency of electromagnetic radiation in physical prophylaxis of harbols. NIVA POVOLZ,A, No 1, pp. 108-110.

[9] Vasiliev A.N., Budnikov D.A., Vasiliev A.A. Modeling the process of heating the grain in the microwave field of a universal electrical module with various algorithms of electrical equipment // Bulletin of Agrarian Science Don. 2016. Vol. 1. No 33. pp. 12-17.

[10] Vasiliev A. Energy-saving system development based on heat pump / A. Vasiliev, I. Ershova, A. Belov, V. Timofeev, V. Uhanova, A. Sokolov, A. Smirnov // Amazonia Investiga. - 2018. - Vol. 7. No 17. - pp. $219-227$.

[11] Izmailov A. Yu., Dorokhov A. S., Vershinin V. S., Gusarov V. A., Mayorov V. A., Saginov L. D. Photoelectric charger of lithium battery, mounted in the vertical leaf of the window frame. Powerman. 2019. No. 1. pp. 20-24.

[12] Belov, A., A. (2018). Modeling the assessment of factors influencing the process of electro-hydraulic water treatment. VESTNIK NGIEI, No 11, 103-112.

[13] Ershova I.G. Heat treatment of fat-containing raw materials with energy of electromagnetic radiation / I.G. Ershova, M.V. Belova, D.V. Poruchikov, M.A. Ershov // International research journal, 2016. - No 09(51). - pp. 38-40.

[14] Belova M. V. Innovations in Technologies of Agricultural Raw Materials Processing/ M. V. Belova, G. V. Novikova, I. G. Ershova, M. A. Ershov, O. V. Mikhailova // ARPN Journal of Engineering and Applied Sciences. 2016. V. 11. No 6. pp. 1269-1277. 